南代〉あはて形に吊卜

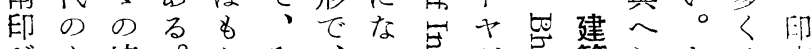

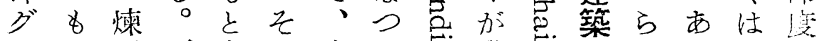

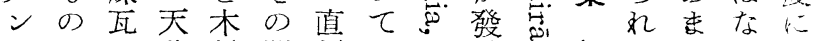

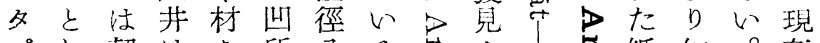
パし契はを所分鸹さ等紙知。存 ”て形木使に米。㞯独面ら阿与

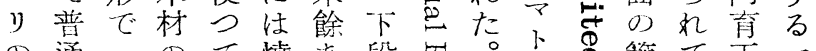

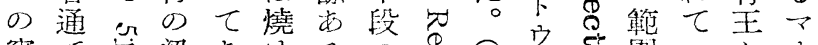

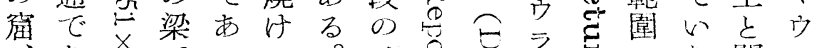

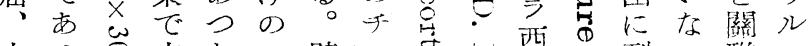

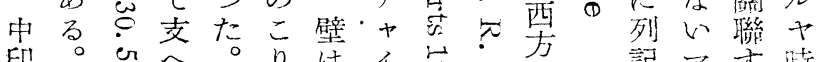

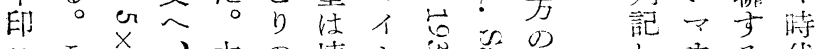

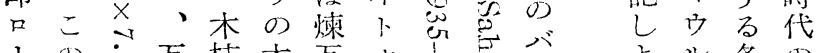

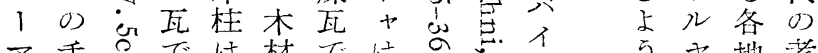

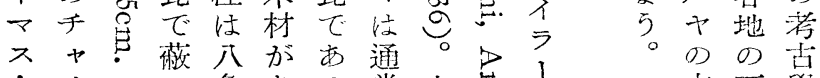
门イのつ解る常小苍占古石學 シ下大て形つがの山惡で物枉的

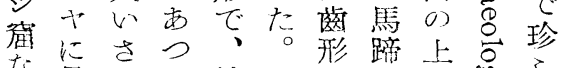

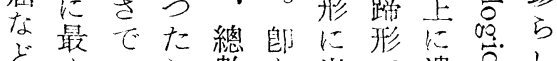

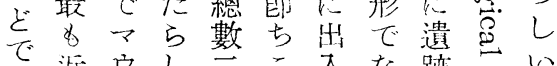

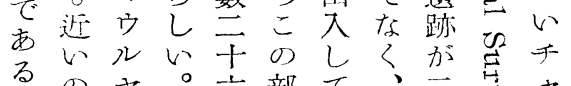

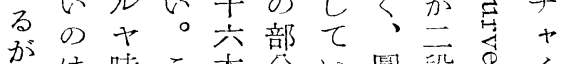

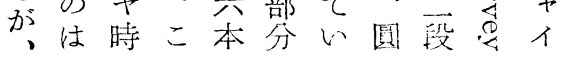
をは溃 窮こ品 屈〉㣂 はにら 亦述古 万べし $\begin{array}{ll}\text { マ } & \text { 時 } \\ \text { ウ } & \text { 告 } \\ \text { ル } & \text { 遗 } \\ \text { ヤ } & \text { 出 } \\ \text { ヤ } & \text { 本 }\end{array}$

時 代 D) 遺

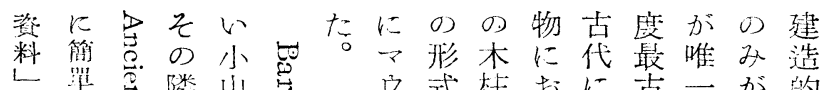
下な导隣山焉ウ式杜打に古一が的 あ記光のが岕ルには心打での發下

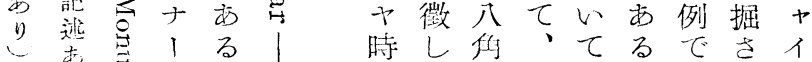

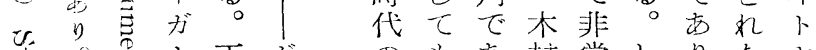

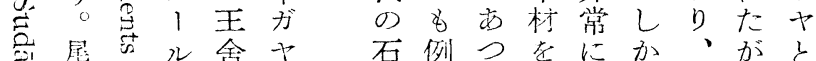

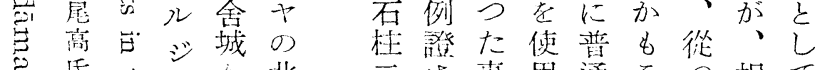

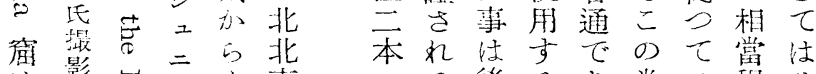
は影孔に東のる後るあ堂こ程サ

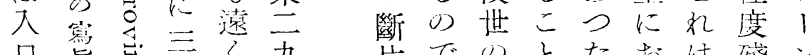

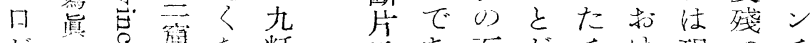

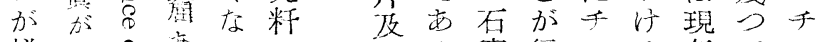

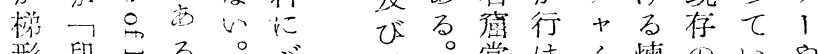
形印芯る。バ整。堂はイ煉のいや

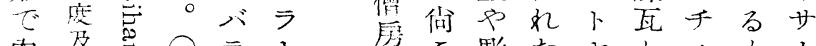
山 本 智

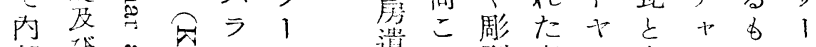

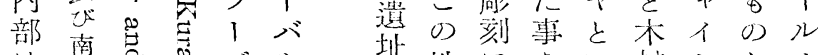

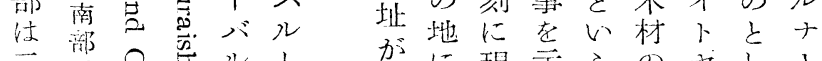

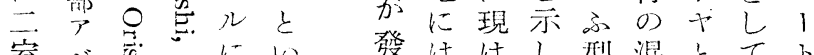
窒ジ富心にい發ははし型混とて下

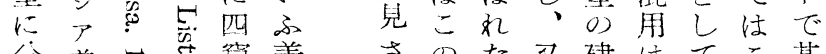

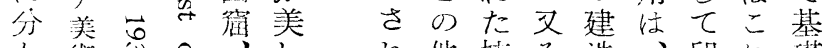

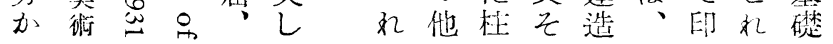


口でに方䎡兩をがり楕、は室咸て五い時は蕯れ は用出の本は支現あと圆有前でるい七てのチで、

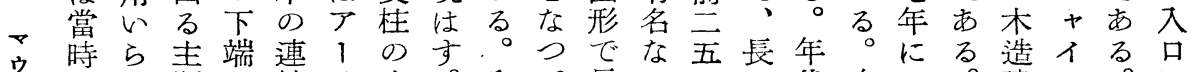
ウ 時ら 表端連 ヤ木たで摩材形間支れい徑。

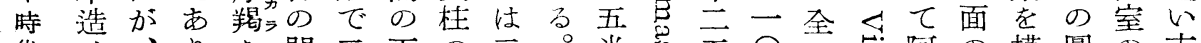

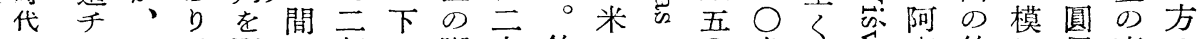
の十こ、配を部の脚本銘二爷 $\bigcirc$ 米同充銘し屋直は

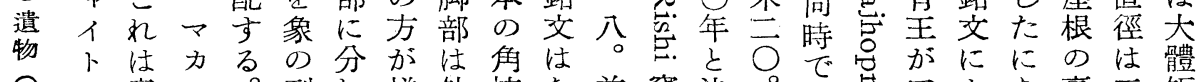

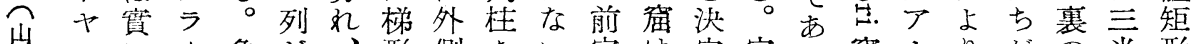

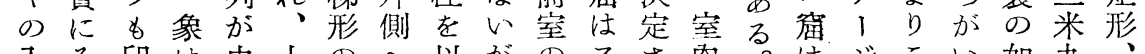

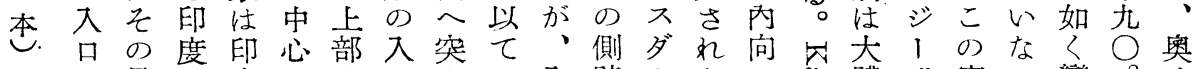

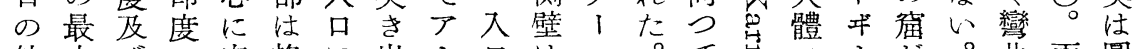
外古びの向格に出、口はマ○て 点スカが。曲兩圓 觀のイ記つ子なし子正よの右点ダに西內し窒形 を遺ン念てをつ、形面く如をに气っ 寄紀部てをで 岩例ト物步表て上卡のに磨々 石总マ進前全心連天

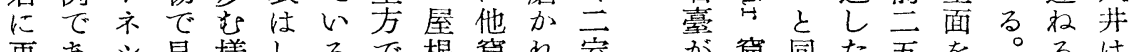

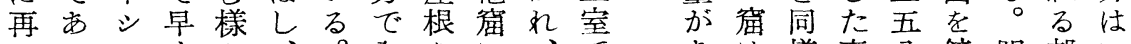

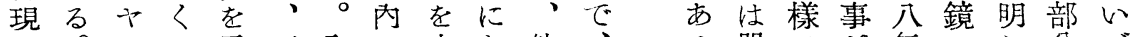

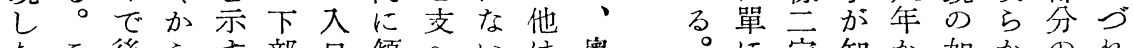
たこ後らす。部口傾へ心は奥知加如かのれ

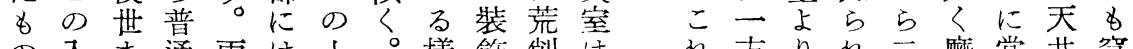

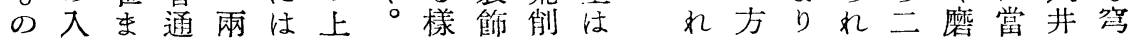

し 城し 吾浯

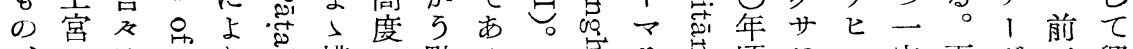
、には

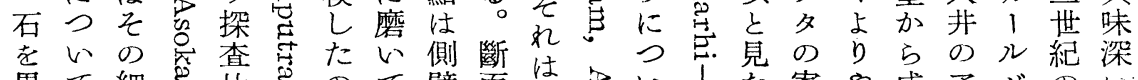

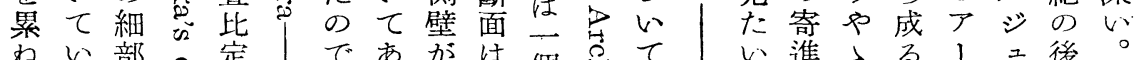

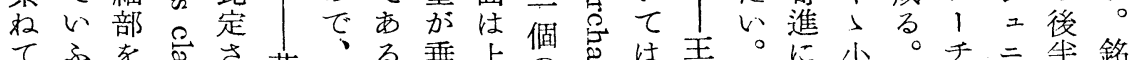

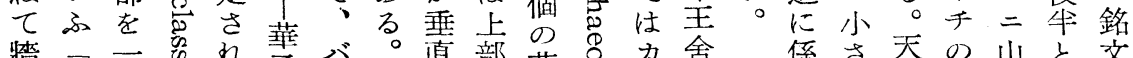

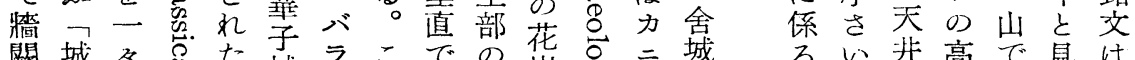

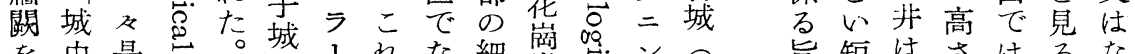

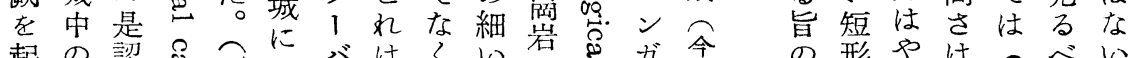

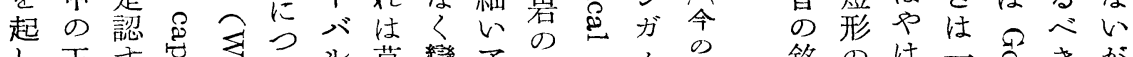

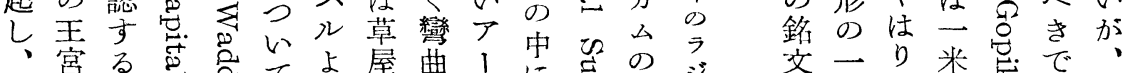
彫殿事

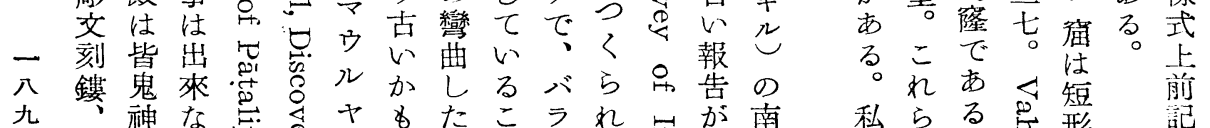

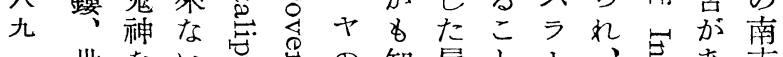

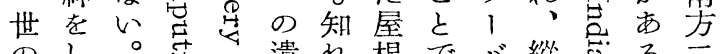

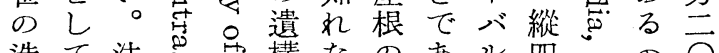
造て法吊構なの市ル四のの $\overrightarrow{0}$

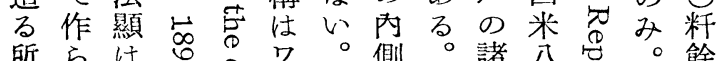

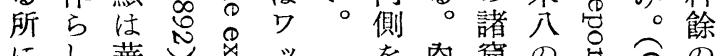

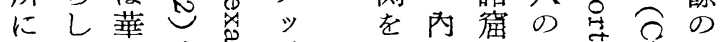
非め子然号デ そ面と短异五 私ら る 点短前

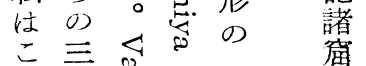

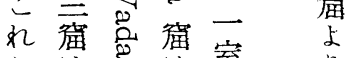
らは芦は室可 を阿案玄だや

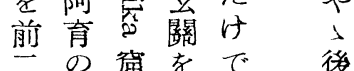




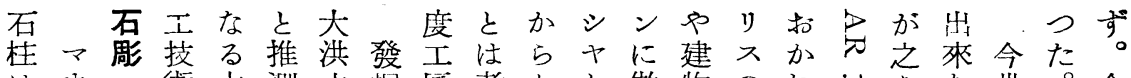

はウ術木測水掘匠考々と做物のれ㟔をた。世。今

別ルせは材さが現のへい令つに百て怘繼。紀方

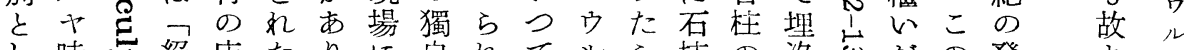

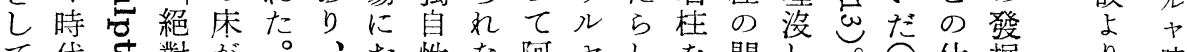

て代导對が。、お性な阿ヤしを間し瓷仕掘り時

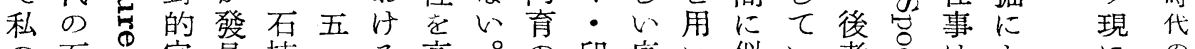

の石の完見桂・る高。の印痕い似い者品よにに

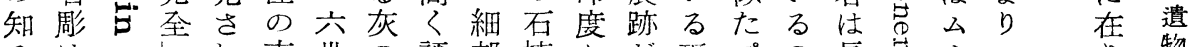

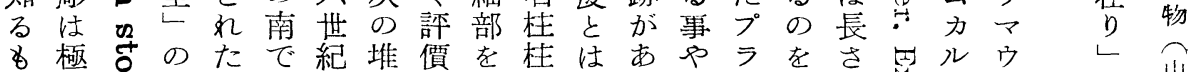

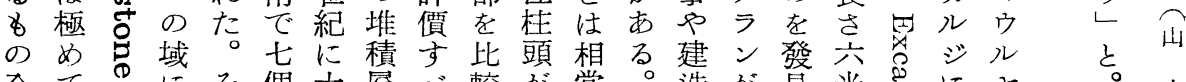

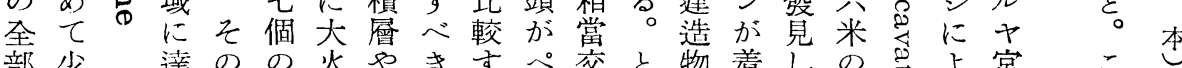

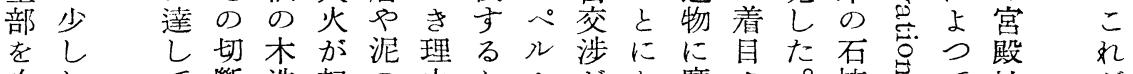

次して斷造起の闰七がか磨さ。桂昆て址加

にかい及のり層が相ポあくを如数き初の五

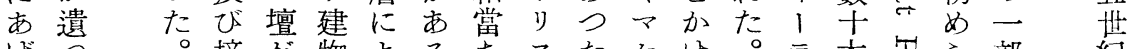

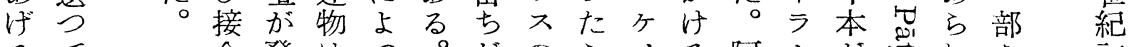

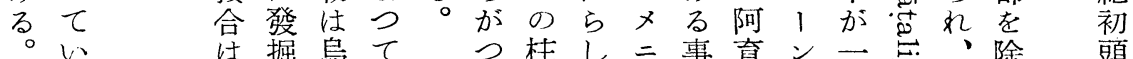

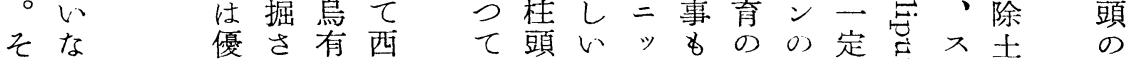

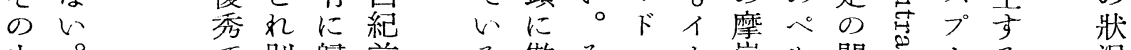

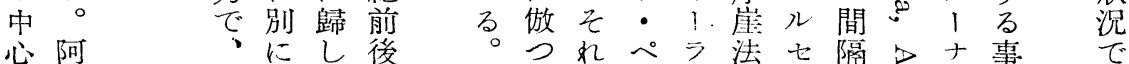

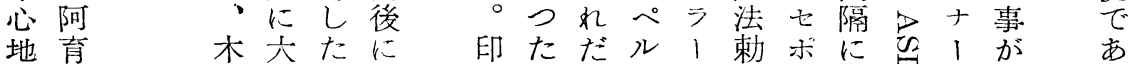

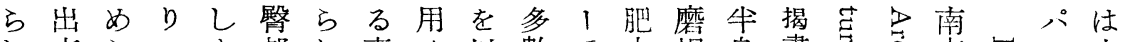

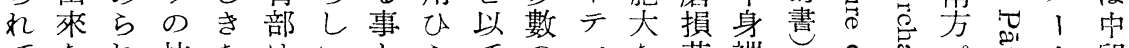

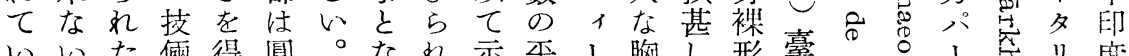

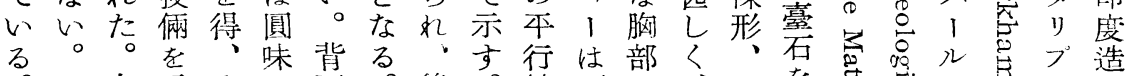

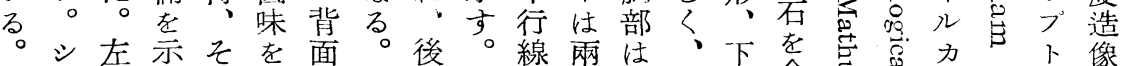

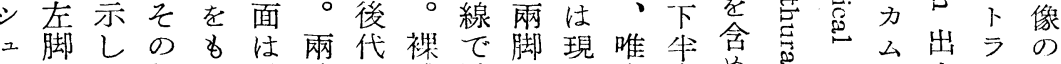

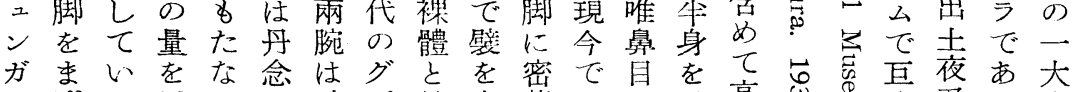
のげる以、で破プ見表著もののだ高岕导像必る中

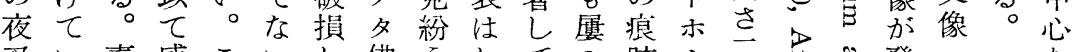

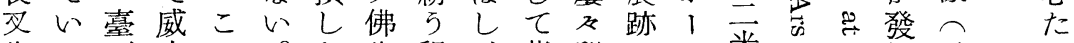
像る石力の。た像程、薄印をテ米只掘、方

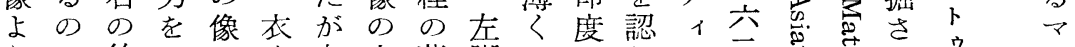

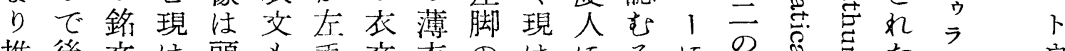

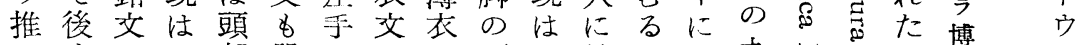

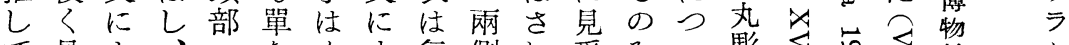

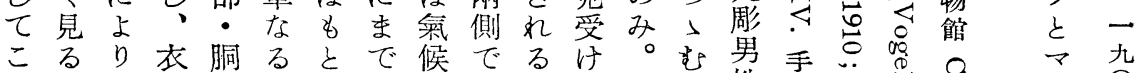

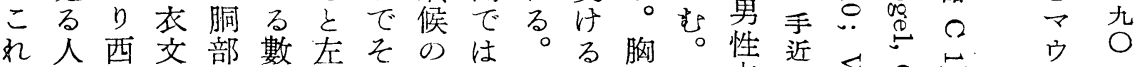

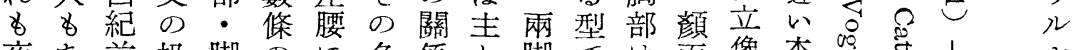

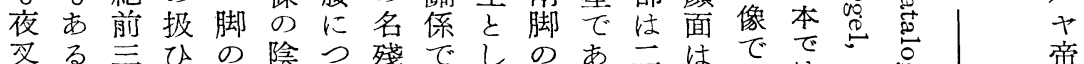

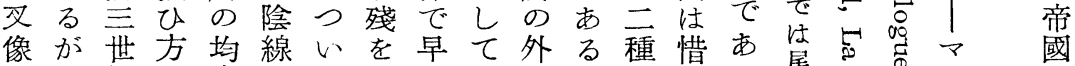

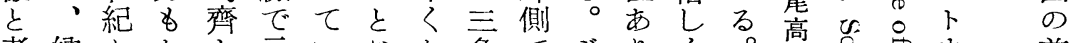

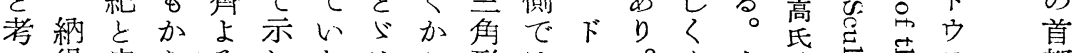

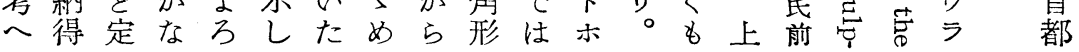


出 $シ ゙$ いバでのしー度に1起卜軀やのマと

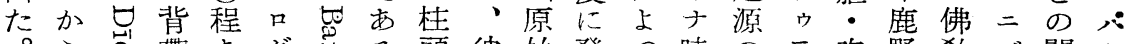

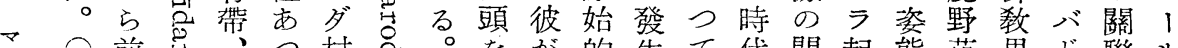

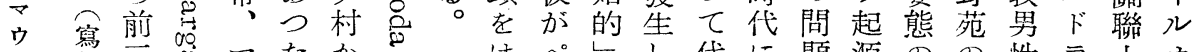

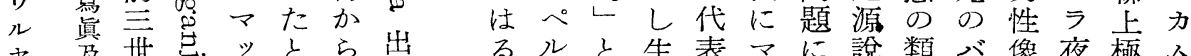

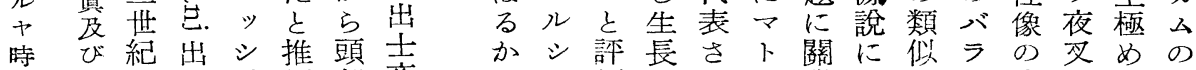
代記に土ヴ㑡部夜上ヤ價しれ门聯も姑此先像て夜 の逝屬夜なさ胸㕛仕・したるラしー警丘祖の注必

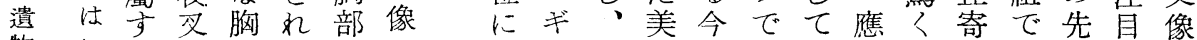

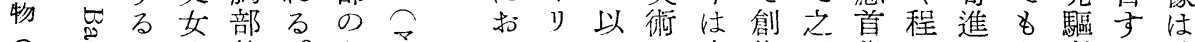

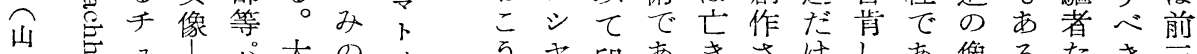

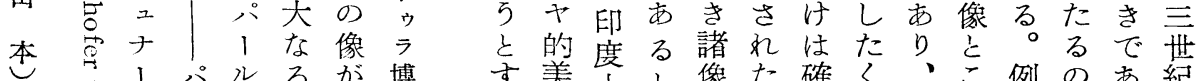
前ルパル るが博す美蒲と像た確く、こ例のあ紀

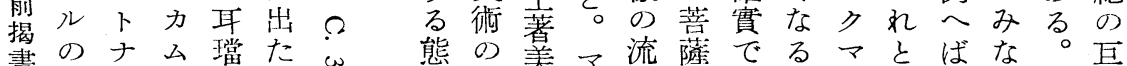

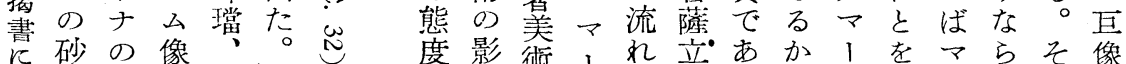

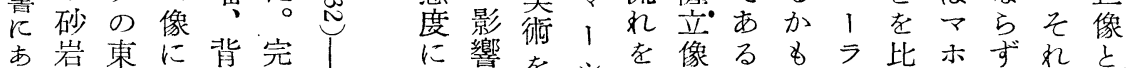
あ岩東に背完

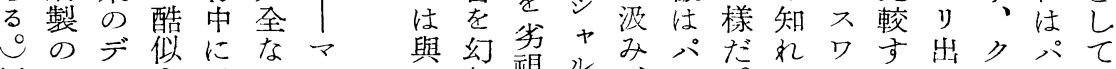

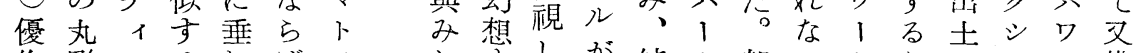

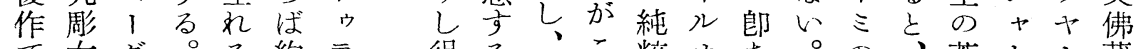

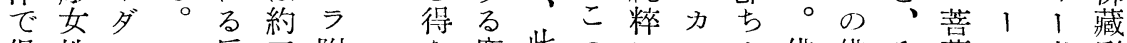

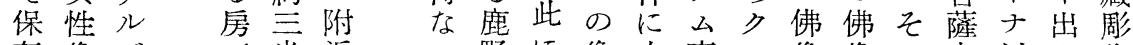
存像ガ・米近 ががン溥七の苑区を印父ヤの體像後の灰

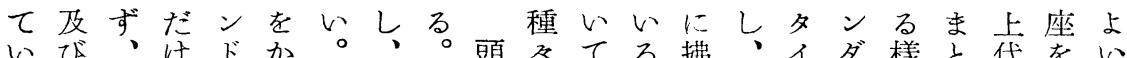
いび、けドが、頭々てる拂、イダ樣と代をい るア面がラこそそ頭部の、事子事ブンなひ印しし ○ンがき派をのの部は特後はを實でグ極、度め類 鼻ド彎わの骨端下前つ相に建方こあ1め身人て例 翼ラ曲立諸がは端面るを現造つれつルて體のいが かのしつ像外彎がにつ指は物侍にた出大各盛るな ら眼てたにか曲と楕る摘れと者近の土な部裝。い 口にい線\&らしの圓にしる同のいでのるにでこの

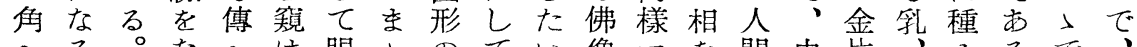
へる○なへは眼〉のてい像マを間中片、るるで、 か。こしられ崰眉裝生ののウなを世の細の上詳そ けそれてれる手ルす㕍に女い裝坐述れ てれをいた樣あ稜が際法ヤ。見到神腹身身しは 八程㓌る。にら線あに上彫全受つ像部具袜た上

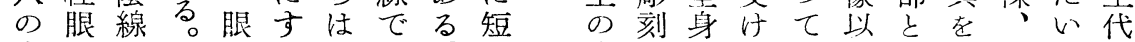
字のでののるする。先のにる來太つ下印

一形開現 上瞼上手圓る前陰路特高の沃の心壮牛を度

九のきは瞼憸法周か額線と色度でし印獒て身略彫

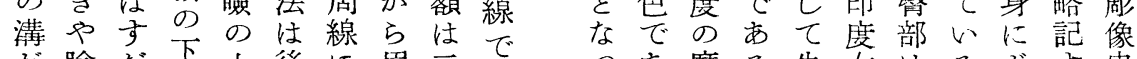

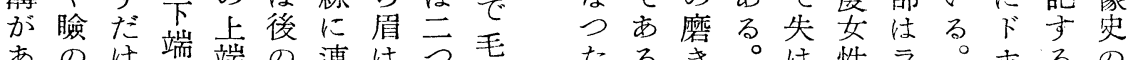

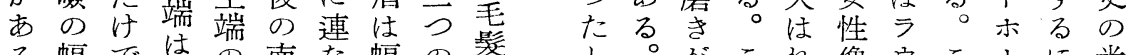

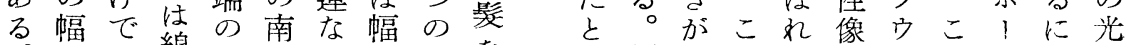

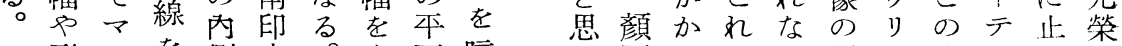

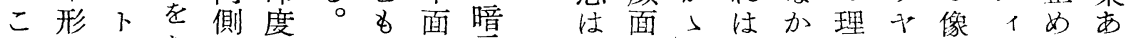
れがウな坐の眼たを示㞦につ右つ想・に、るる は似ラさ分ア曧ななするて手た的ナ見を。王 
ジあナロでててしの行事てるる次トにいるが、同

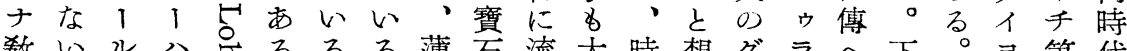
教、ルハ怘るるるる薄石流大時想グラへ下第代 の○の二氖。嫌布のれ體代ふプのら唇こン元の

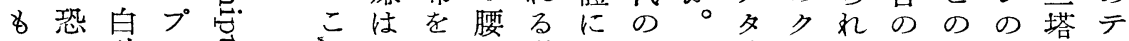
のら砂ル芯市ま帶陽お下グ時シた中點頭のラ

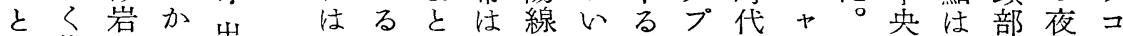

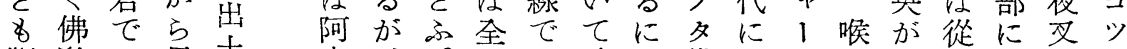

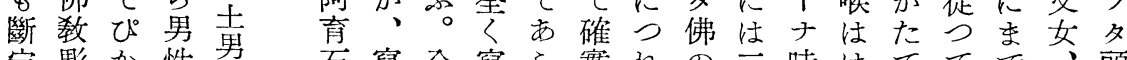
定彫か性男石寫全寫ら實れの好の時はててで、頭 出刻ぴ立性柱實體實はなと場つ代つにマ見バ部 來でか像像々にと的し事の合のにきや下らルル なはにのパ 同發しで。實盛は部はり〉ウれハ次

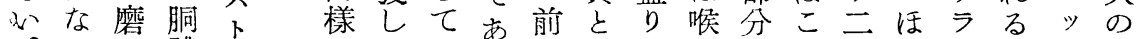

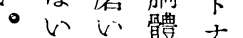
だてが博 $\begin{array}{llll}ら & \text { あ } & \text { 出 } & \infty \\ 5 & る & た & \stackrel{0}{1} \\ \text { か } & 0 & 0 & \infty\end{array}$ 古。 にて上面い上のにれつれのがト時 ウ $ヤ$ 時 代 の 遺 物 Н

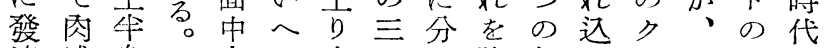
達感身背央よ方う加陰部九シ之神の

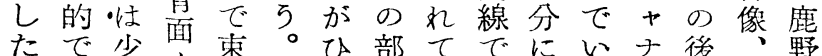
たで少を整。ひ部てでにいナ後、野

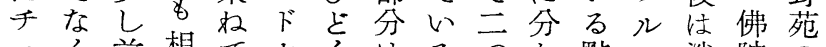
さ裸料 れではパ ば何やト とのはナ 以裝り附 $つ$ 身于近 二く前相てホくはるら加點は消陀の ナ威加當垂、な盛のにれ染圽伽頭 1 嚴 ゙ 丹 らテつ りと分て

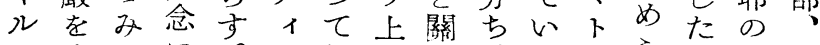
のそにに。、行ら聯、るウら特蓮サ 美なな處五はつてがて。色花、

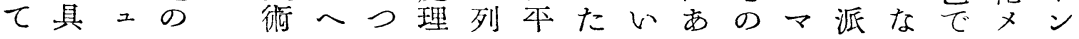

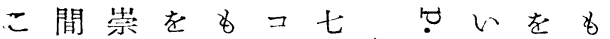

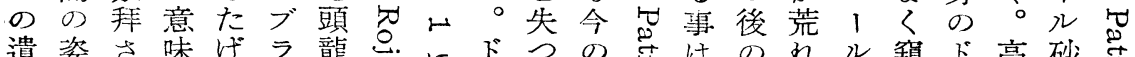

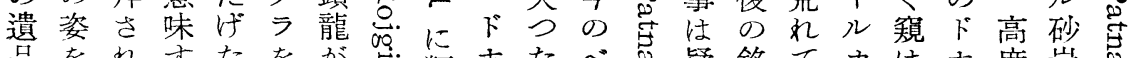

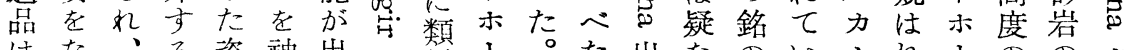

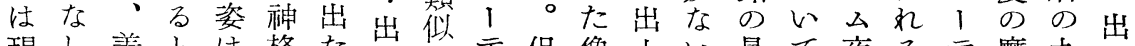

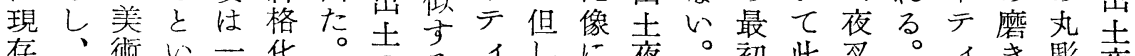

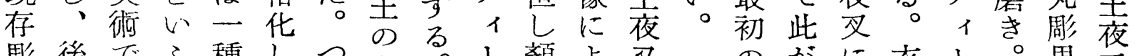

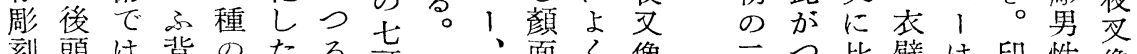

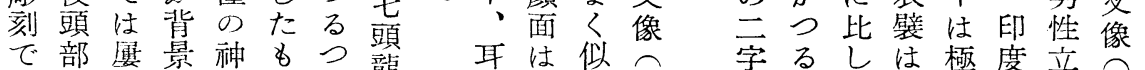

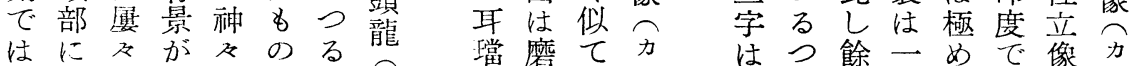
最コ、あしでにカ もブ多るさあ、磨ル 腕しるッ⿻ 峁で柔は薄く等タ

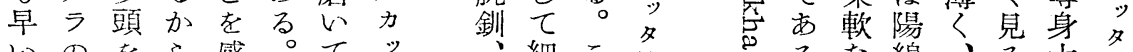

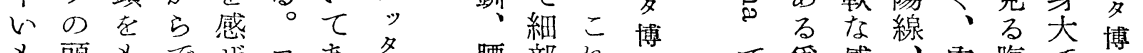

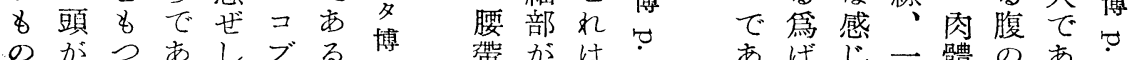

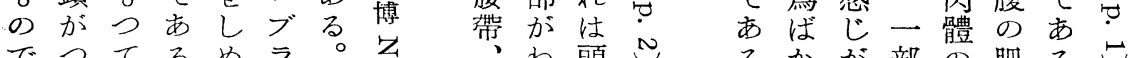

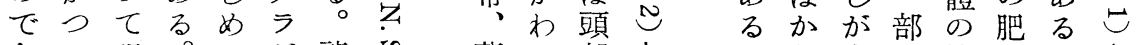

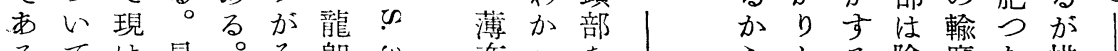
るて 以さくそのちら線が男し褐 る好かの构于 衣いす土思杜でそでく灰

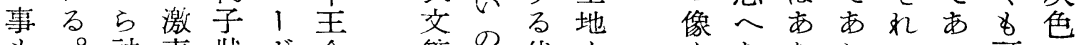
\&。神毒狀ガ舍 等の代も多ななる るる頭の あ時とがのは城前はり大夜いがは通。部于 るにし師頭毒か 述惜脚い文。ち方し下をを 人て死を蛇 5 のし部さた屃彼。て牛缺ナ 


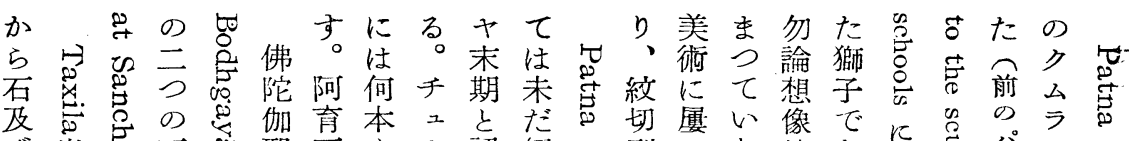

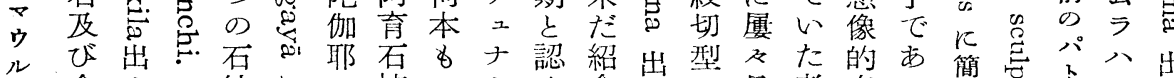

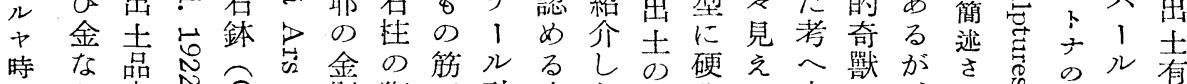
代

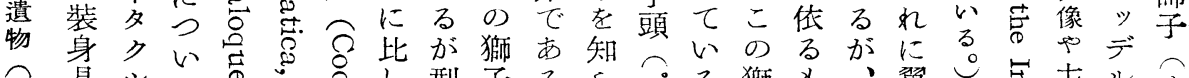
山其

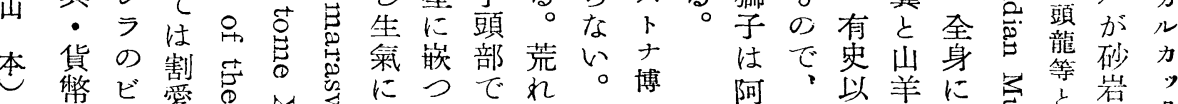

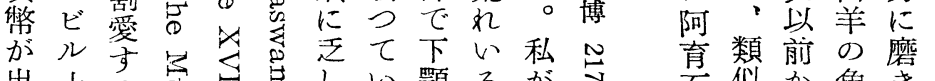

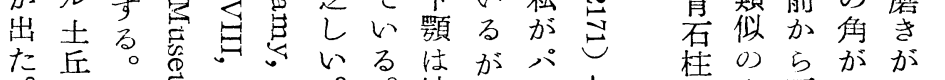

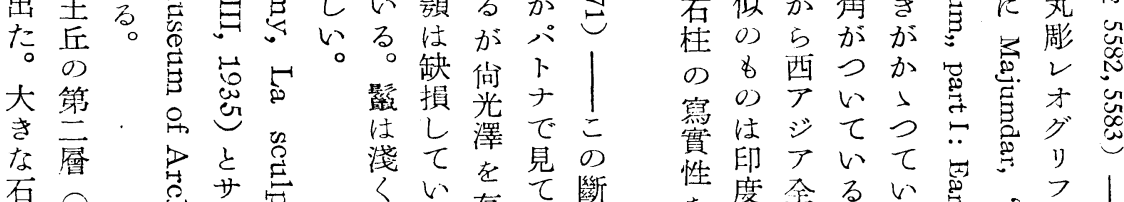

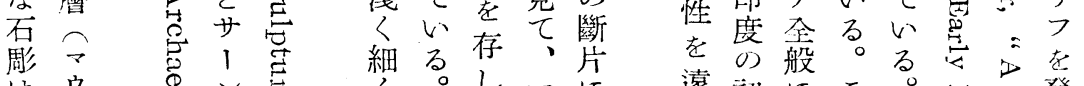

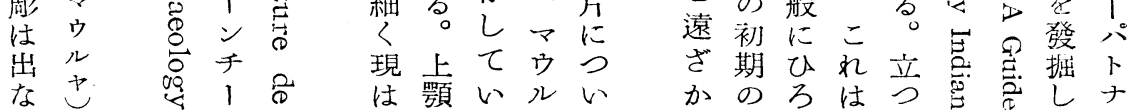

のり方市一かてを頭すいかはいい 出点行面る地でにマテ同て大飾へ樣儿知桇砂配— 土臣好の研印は、多ウラ樣いきはきでカら怠岩す個

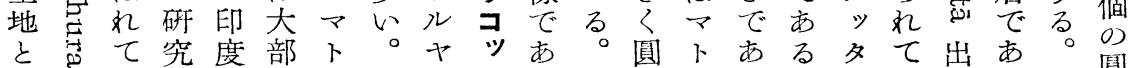

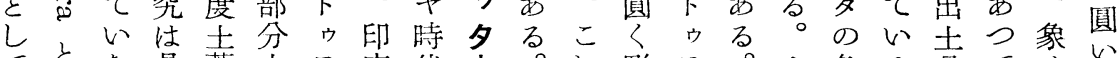

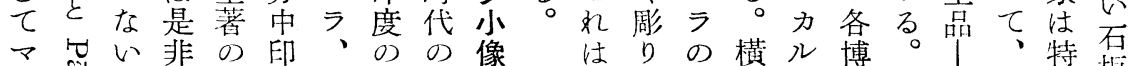

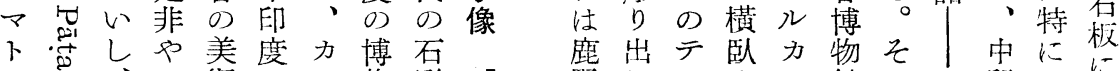
ウ㤩、ら術のル物彫今野しラせッ館のビ印生に

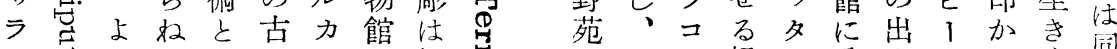

といばし地ッで極祭の上ッ婦に分土夕ら/间

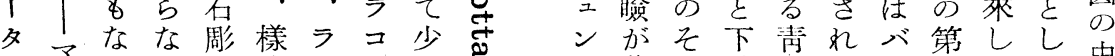
ガ薄れ肢いたナ四たて中

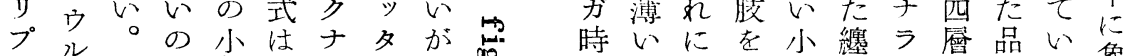

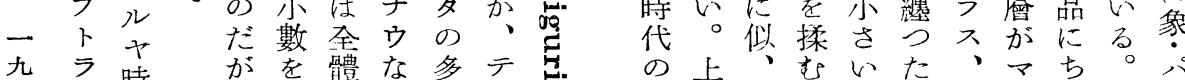

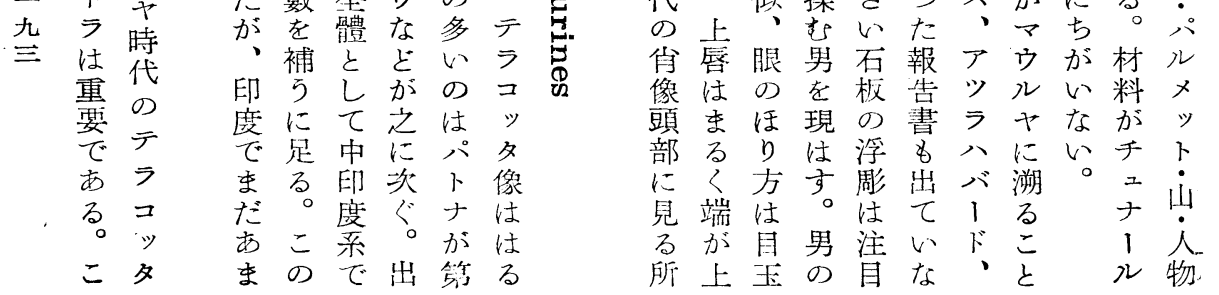


でい性导石る代中五?がき後てれ女てはがいて 、可左にウあく世いる皮、共マがいを ここ乳女金タはの頭ルるななのる。る゙眼に水 ののが子細、廢た飦ヤ。い佛。第そ寓盛ウ大と較 時事大は工バれまで・こ。像こ主のののりラ體概手 代はき勿等ンたのあシれ第とのに後輪上はの言る に印く論を以と方るュは四は點鼻の廓つ大特出と 限度又男も外見ががンデにち岋は古をてをき徴來首 るの隆子つにえ大! 方、口が同兩代あいくをる都 わ各起 \&て頭てき男の

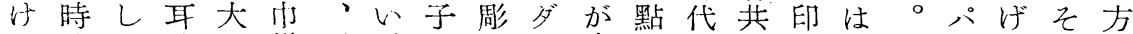
で代て璫き樣彫。は像ル鹪での亦度すそ、るのが

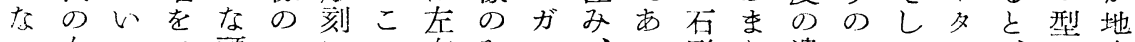
心女るつ頭もにの右みン、る彫り遺はてり、忧方 ○性のけ飾の見樣ににジ鼻。と高品石眼プ第色都

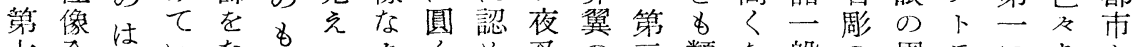

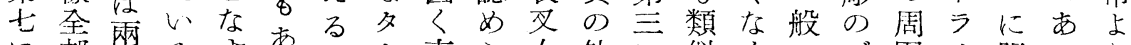

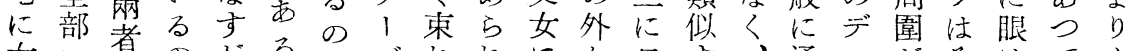

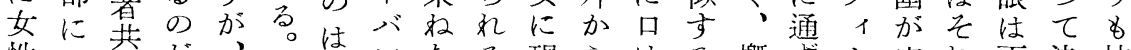
性つ殆が、女别ンたる現らはる概ず

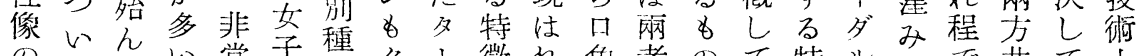

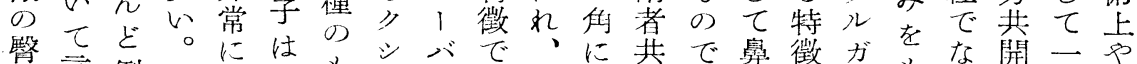

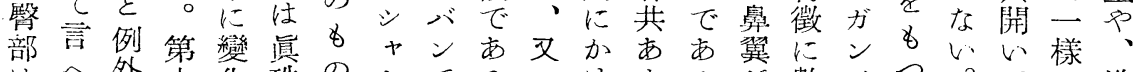

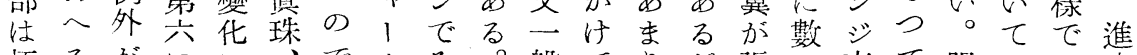
極るがににでナと般てりが張へ夜て眼い捗

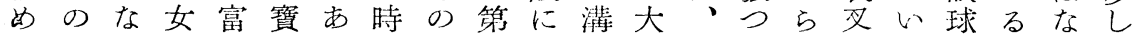

知がすやつンガ四 實と上時衣肉いの旗るでて

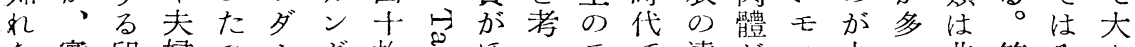

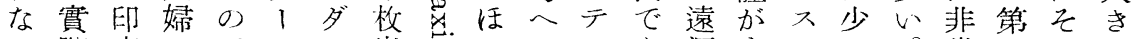
際度のでラ 1 出芯ら゙らラも源すリい。常八如い の的飛市派 用で天るのに方夰で度こしをで十多女で腹 途は哇。興近だらい及衣子て現概にい性な部

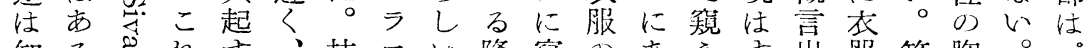
知る 岁和す、技コ以隆竄の市えす出服第胸。， らが恕らる 前法ッ。鼻さ特るるる 來は厹邻こ

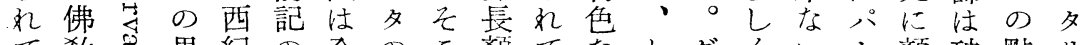
て教 灾男紀の全のこ顏てなとグくい，顏破點り

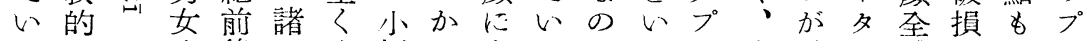
なでな像後地中板ら合るたふふタ肉、リ體し一下 いなどはまか印に先致民と鹃子プのて般ラ 、を只でら度男のし族言り彫にト卜形いにで 或思同点は杜式憶な的女像密口ラはる印は

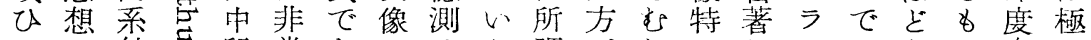

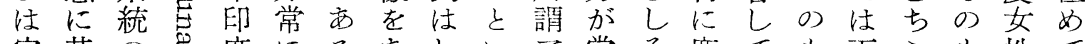

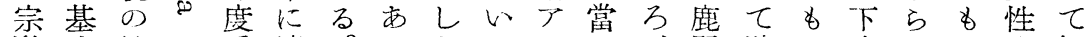

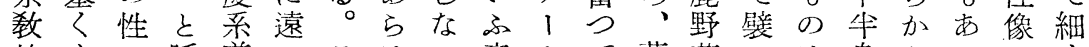
的もの呼美いこ杪、意ルて薄苑をは身とるのく なの歡ば術ののす。味ヤい衣の有如のいが通 護でび礼圈た地子深ンは佛し何のへ、有、 符あをる为がはの長のう何像なにこばそ性卜 から肯群に”北が特。時のいるる圓のでゥ \&5定像あ ガ部約事徵以の薄。溥も顔種市 


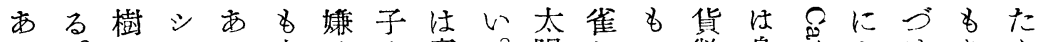

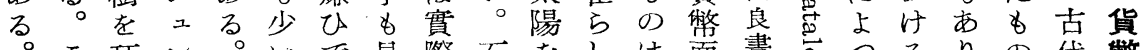

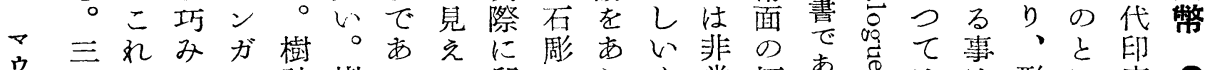
ウつはにの神樹つるる印にら常䅺古仙は形に度 ヤの三現記の木たが度あはのに章过吊と团は分の

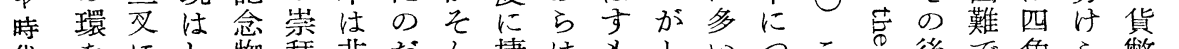
代をにし物拜非たん棲は好とつこの後で角ら幣

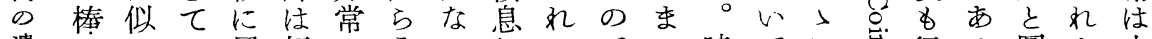
遺でてい屚既にうにしるでつ時てに苞行る圓よ大

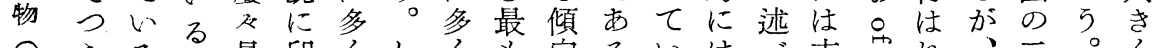
出ら る 本い、牛所河大しなし

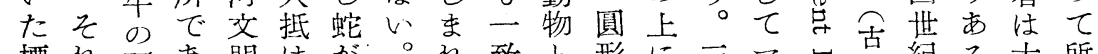
標狆頭あ明は肪。れ致と形に三マ占代紀る大所

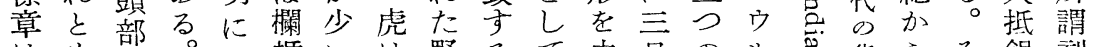
はも

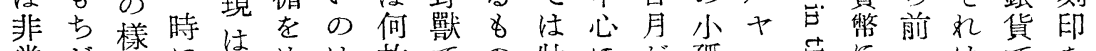

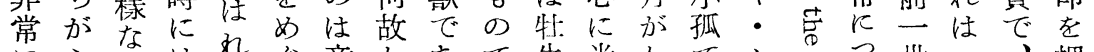

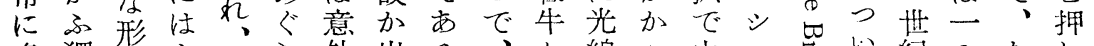

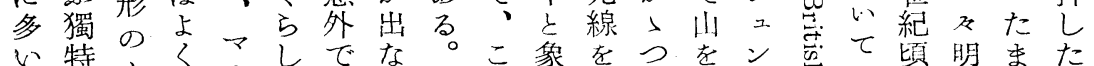

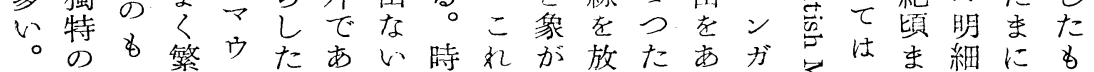

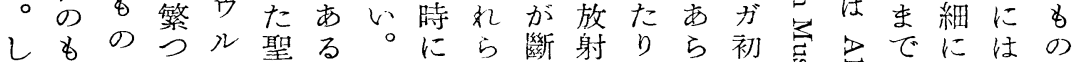
かのがたヤ樹し虎は然す、は期芯芯、年銅と しであ大・市魚は獅つ多る孔すの志吉所代貨鑄

に要をドン占ジにに最てにい印幣學にも何恐と 潤請象ラスにナ灌打もい小のをで者は母なるらの

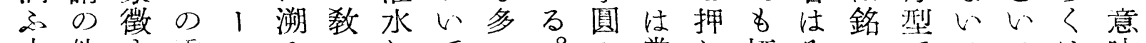
大他于乘ンる・してい。の當し標々のでこつは味 地にるり時汎印ては欄つ然た章の鎆とて种は

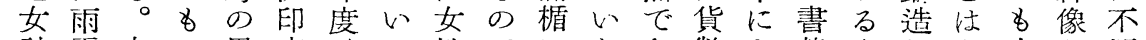
神堅左の黑度教る性でにたあ幣よ態もしな中を明 とは右とい的の意像あ圍子るとつにのたい印解で 考象に定雨意石匠肪る李の。共てょる貨。かすすあ

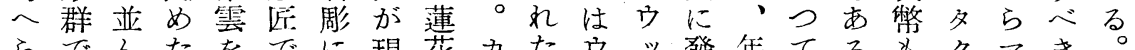
らでんたをでに現花力たウッ發年てるるもクマき 如あで樣見あ女狆臺ウ聖ッ腹見代年。非シ、で又

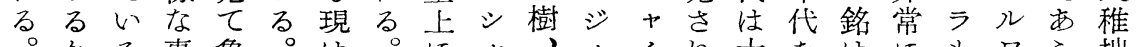

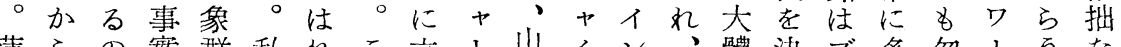
蓮ら の實群私れこ立!山!イン゙、體汱ブ多忽! う。

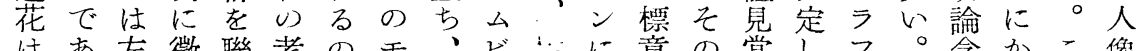
はあ左徴聯考のモ、ビ、、に章の當しプ含かこ像

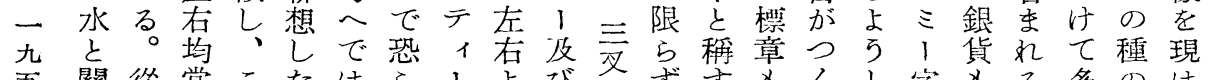

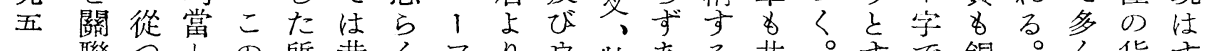
聯つとの所者くフりウ牡ある共。すで銅。く貨す

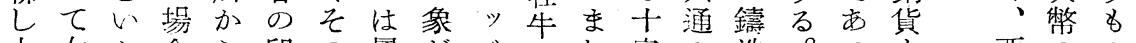

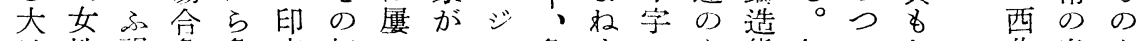

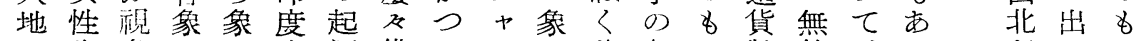
の像角はを人源佛のイな普各の幣銘、る印士あ 豐は上雨イがは敎頭二ど及尖がはの古。度地る

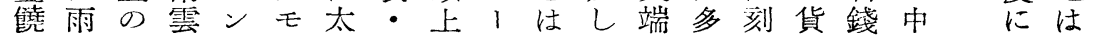




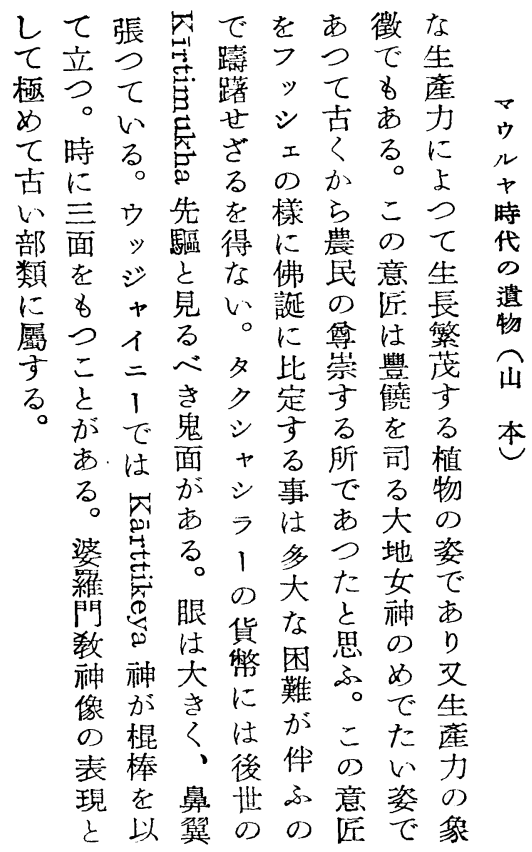

\section{近年インドにおける記念論文集 II}

A Volume of Indian and Iranian Studies presented to Sir E. Denison Ross (Bombay, 1939 ; New Indian Antiquary, Extra Series II )

Woolner Commemoration Volume (Lahore, 1940 ; Mehar Chand Lachhman Das Sanskrit and Prakrit Series, 8)

D. R. Bhandarkar Volume (Calcutta, 1940)

A Volume of Studies in Indology presented to Prof. P. V. Kane (Poona, 1941)

Silver Jubilee Volume, Bhandarkar Oriental Research Institute, 1917-1942 (Poona, 1942 ; Annals of the Bhandarkar Oriental Research Institute, vo1. 23)

B. C. Law Volume, Parts I and II (Calcutta, 1945 ; Poona, 1946)

Bhārata-Kaumudi-Studies in Indology in honour of Dr. Radha Kumud Mookerji, Parts I and II (Allahabad, 1945, 1947)

Dr. C. Kunhan Raja Presentation Volume : a Volume of Indological Studies (Madras, 1946)

Acharya Dhruva Smaraka Grantha, Acharya Dhruva Commemoration Volume (Ahmedabad, 1946)

Shri K. M. Munshi Diamond Jubilee Volume, Part I (Bombay, 1949)

Homage to Vaisali. Ed. by J. C. Mathur and Yogendra Mishra (Vaisali, 1948)

Sir William Jonens. Bicentenary of his Birth, Commemoratian Volume, 1746 -1946 (Calcutta, 1948)

(JAOS. 71-1, Jan.-Mar. 1951, p. 88 より) 